\title{
Implementasi Transformasi Branding Kota Cimahi Sebagai Kota Kreatif
}

\author{
Nada Arina Romli ${ }^{1}$ \\ Universitas Negeri Jakarta ${ }^{1}$ \\ nadaarina@unj.ac.id
}

\begin{abstract}
Abstrak: Penelitian yang berjudul Implementasi Transformasi Branding Kota Cimahi sebagai Creative city bertujuan mengetahui implementasi kampanye yang dilakukan Pemkot Cimahi kampanye perubahan merek Creative and Cyber (C4) menjadi Creative city dengan program pengembangan ekonomi lokal (PEL). Penelitian ini mengkaji proses pembangunan makna yang melibatkan interaksi sosial Pemkot Cimahi dan target audiens dalam perubahan merek Kota Cimahi sebagai Creative city. Penelitian ini menggunakan metode penelitian kualitatif, dengan paradigma konstruktivis, dan jenis studi kasus. Penelitian ini menggunakan teori interaksi simbolik dari George Herbert Mead. Subjek penelitiannya adalah PNS Pemkot Cimahi serta wirausahawan yang tergabung di komunitas kewirausahaan di Cimahi yang dipilih dengan teknik sampling purposif. Pengumpulan data diperoleh melalui teknik wawancara mendalam, observasi partisipan pasif, dan kajian pustaka. Hasil penelitian mengungkapkan bahwa dalam upaya menciptakan makna bersama Cimahi sebagai Creative city antara Pemkot Cimahi dan target audiens dibutuhkan sosialisasi Pemkot Cimahi kepada target audiensnya yaitu wirausahawan sebagai target utama dan masyarakat umum sebagai target kedua dengan menggunakan berbagai jenis pola komunikasi diantaranya pola komunikasi interpersonal antara Pemkot Cimahi dengan individu wirausaha di Cimahi serta masyarakat umum adalah dengan melaksanakan Forum Temu Usaha yaitu sebuah seminar dan workshop yang menghadirkan berbagai pakar wirausaha yang diundang oleh Pemkot Cimahi serta komunitas wirausaha Cimahi diantaranya Cimahi Creative Association (CCA) yang bergerak di bidang teknologi animasi, Ikatan Wanita Pengusaha Indonesia (IWAPI) regional Cimahi, Komunitas Kewirausahawan Muda Cimahi (KWACl). Pola komunikasi organisasi yang dilakukan pemerintah kepada komunitas wirausaha dengan menggunakan media sosial, selain itu pola komunikasi organisasi pun dilakukan dengan menggunakan media luar ruang seperti poster yang ditempel di tempat-tempat pertemuan komunitas wirausaha dan mading Pemkot Cimahi, menyelenggarakan pameran kewirausahaan, membuat gerakan "Cinta Produk Lokal Cimahi", membuat website PEL, promosi menggunakan media sosial seperti Facebook serta, melaksanakan Forum Group Discussion Sementara pola komunikasi massa yang dilakukan oleh Pemkot Cimahi kepada masyarakat umum untuk mensosialisasikan perubahan merek Kota Cimahi yaitu dengan mengundang jurnalis untuk peliputan dan penayangan di TV nasional maupun lokal, memasang iklan di TVRI, dan menyelenggarakan Talkshow anggota PEL menayangkan TVRI, dan membuat buku profil komunitas wirausaha Cimahi Kata kunci: Branding, Cimahi, Kota, Kreatif, Kampanye
\end{abstract}

Kota Cimahi diketahui oleh masyarakat sebagai "Kota TNI" karena banyak ditemukan pusat pendidikan untuk TNI. Ada 24 bangunan militer yang juga didaulat sebagai Cagar Budaya yang dilestarikan di Kota Cimahi. Cimahi telah menunjukkan perkembangan yang pesat sebagai kota otonom yang memiliki pembangunan, pertanian, serta industri kreatif maupun manufaktur. Namun Cimahi mempunyai keterbatasan lahan yaitu 4.036,45 Ha (sumber: RTRW Kota Cimahi 2011-2013) serta tidak memiliki sumber daya alam sedangkan jumlah penduduk yang semakin membengkak yaitu sebesar 541.177 jiwa berdasarkan sensus penduduk tahun 2010 (sumber: Kota Cimahi Dalam Angka Tahun 2011). Ditambah 
dengan angka pengangguran yang relatif cukup besar, pada tahun 2010 sebesar 13,59 diatas tingkatan pengangguran Provinsi Jawa Barat pada tahun yang sama (10,33\%) (Dokumen PEL Kota Cimahi 2013-2018).

Sehingga pada tahun 2007, Kota Cimahi berupaya mengubah branding kota sebagai "Cimahi Creative and Cyber City" dengan membentuk CCA (Cimahi Creative Association) dengan fokus pada pengembangan industri kreatif yaitu dibidang manufaktur, kuliner dan kerajinan serta industri digital yaitu pengembangan ICT, animasi dan film yang dipusatkan di wilayah Baros. Tetapi program "Cimahi Creative and Cyber City" tidak efektif. Maka dari itu, tahun 2011 Pemkot Cimahi membuat sebuah kampanye perubahan merek kota Cimahi yang pada awal sebagai Creative and Cyber City menjadi Creative City melalui program Pengembangan Ekonomi Lokal (PEL) dengan menggandeng komunitas kewirausahaan yang ada di Cimahi.

Kampanye merupakan alat yang digunakan public relations untuk berkomunikasi dengan audiensnya. Yin (2006:49) mengungkapkan bahwa fokus dari penelitian studi kasus adalah penelaahan kasus yang spesifik dan memiliki unik. Keunikan kasus ini berdasarkan pemaparan beberapa informan adalah (1) Pemkot Cimahi sangat berkonsentrasi pada perubahan merek kota. (2) Cimahi memiliki produk unggulan yaitu industri digital yang berpotensi. (3) kampanye ini membangun sense of belonging antara Pemkot dan masyarakat sehingga penyelenggaraan kampanye dilakukan bersama-sama.

Berdasarkan penjelasan diatas penulis melakukan penelitian dengan judul "Pola Komunikasi Perubahan Merek Kota Cimahi Sebagai "Creative City" dengan tujuan untuk mengetahui bagaimana implementasi kampanye yang dibangun Pemkot Cimahi kepada para pelaku usaha dan masyarakat di Cimahi agar terjadi persetujuan merek baru kota Cimahi sebagai Creative City..

\section{METODE}

Penelitian ini menggunakan metode penelitian kualitatif yang artinya peneliti turun ke lapangan dan terlibat menjadi instrumen penelitian. Sampel penelitian tidak hanya sebagai objek penelitian tapi juga subjek dan setara dengan penelitinya. Oleh karena itu peneliti dalam penelitian kualitatif harus memasuki latar natural dari penelitian dan bergabung dengan subjek penelitian. Perspektif subjek penelitian diutamakan dalam penelitian kualitatif, meskipun terdapat perspektif peneliti, tetapi peneliti tidak menonjolkan pandangannya tersebut.

Penelitian ini menggunakan paradigma konstruktivis karena penelitian ini mencoba membangun makna bersama target audiens tentang Kota Cimahi sebagai Creative City melalui program PEL, hal ini sesuai pemaparan mengenai konstruktivisme, yakni filsafat pengetahuan yang meyakini bahwa pengetahuan manusia merupakan hasil konstruksi dari manusia itu sendiri (von Glasersfeld dalam Bettencourt, 1989 dan Matthews, 1994, seperti dikutip oleh Suparno, 1997:18). 
Selain itu penelitian ini pun memfokuskan pada jenis studi kasus hal ini berdasarkan pengertian Creswell yang mengemukakan beberapa karakteristik dari suatu studi kasus yaitu : (1) menelaah suatu "kasus" terkait suatu studi; (2) Kasus tersebut terikat pada waktu dan tempat tertentu; (3) Studi kasus menggunakan banyak sumber informasi dalam pengumpulan datanya untuk memberikan gambaran secara detail suatu peristiwa dan (4) Menggunakan pendekatan studi kasus, peneliti akan memfokuskan diri dalam menggambarkan konteks atau setting untuk suatu kasus. (Creswell, 2012: 36-37)

Penelitian ini diteliti saat kampanye perubahan merek kota Cimahi sebagai creative city ini masih dilaksanakan dan dilakukan oleh Pemkot Cimahi pada tahun 2011 hingga tahun 2018. Penelitian ini pun menggunakan berbagai teknik pengumpulan informasi diantaranya: observasi, wawancara, materi audio-visual, dokumentasi dan laporan pertanggung jawaban setiap program kampanye.

Fokus utama pada penelitian studi kasus adalah penelaahan suatu kasus yang spesifik dan unik, penelitian ini termasuk pada kasus yg unik karena pertama, pemerintah dan target audiens bersama-sama berperan dalam kampanye ini. Kedua, Creative City Cimahi mengembangkan industri digital dimana kota lain tidak ada yang mengembangkan industri digital. Yang ketiga pemerintah dan masyarakat bersama-sama memajukan UMKM hal ini tercermin dalam visi dan misi Pemkot Cimahi, sehingga penelitian ini sesuai jika ditelaah dengan penelitian studi kasus.

Dalam penelitian mengenai kampanye perubahan merek kota Cimahi sebagai Creative City, peneliti menggunakan teori Interaksi Simbolik dari George Herbert Mead sebagai pisau analisis. Interaksi simbolik merupakan komunikasi atau pertukaran simbol yang diberi makna. Interaksi simbolik berasumsi bahwa manusia dapat mengerti berbagai hal dari pengalaman dan interaksi sosial.

Karya Mead yang paling terkenal ini memaparkan 3 konsep mengenai teori interaksionisme simbolik. Tiga konsep ini saling mempengaruhi satu sama lain dalam term interaksionisme simbolik. Dari itu, pikiran manusia (mind) dan interaksi sosial (diri/self dengan yang lain) digunakan untuk menginterpretasikan dan memediasi masyarakat (society) di mana kita tinggal. Makna berasal hanya dari interaksi. Pada saat yang sama "pikiran" dan "diri" timbul dalam konteks sosial masyarakat. Pengaruh timbal balik antara masyarakat, pengalaman individu dan interaksi menjadi bahan bagi penelahaan dalam tradisi interaksionisme simbolik (Ardianto, 2007: 136).

Dalam penelitian ini peneliti mengaplikasikan teori interaksi simbolik dengan mengupas bagaimana implementasi kampanye perubahan merek Kota Cimahi Sebagai Creative City yang dilakukan oleh pemkot Cimahi serta komunitas-komunitas yang terlibat. Kemudian orang-orang yang terlibat dalam kampanye menerjemahkan simbol dalam pikiran (mind) kemudian melakukan pertukaran makna melalui (self) kemudian 
menyetujui pendapat yang sama mengenai merek kota Cimahi yang baru sebagai Creative City dalam masyarakat (society).

\section{HASIL}

Dalam penyelenggaraan kampanye perubahan merek kota Cimahi sebagai Creative City diperlukan sosialisasi kepada target audiens mengenai apa saja program kerja atau kegiatan yang akan dilaksanakan guna mendukung Cimahi menjadi Creative City. Target audiens utama dalam kampanye ini merupakan pelaku usaha mikro dan menengah, dimana kegiatan-kegiatannya adalah untuk mengembangkan usaha serta SDM pelaku usaha tersebut, dan dilakukan sosialisasi agar pelaku usaha tersebut ikut berpartisipasi aktif bersama Pemkot dan SOPD dalam setiap rangkaian program kerja atau kegiatan. Selain itu masyarakat di Cimahi pun menjadi target audiens kedua dalam mensosialisasikan kampanye ini.

Berikut hasil penelitian mengenai pola komunikasi kampanye perubahan merek kota Cimahi sebagai Creative City yang dilakukan Pemkot Cimahi kepada pelaku usaha UMKM dan masyarakat di Cimahi:

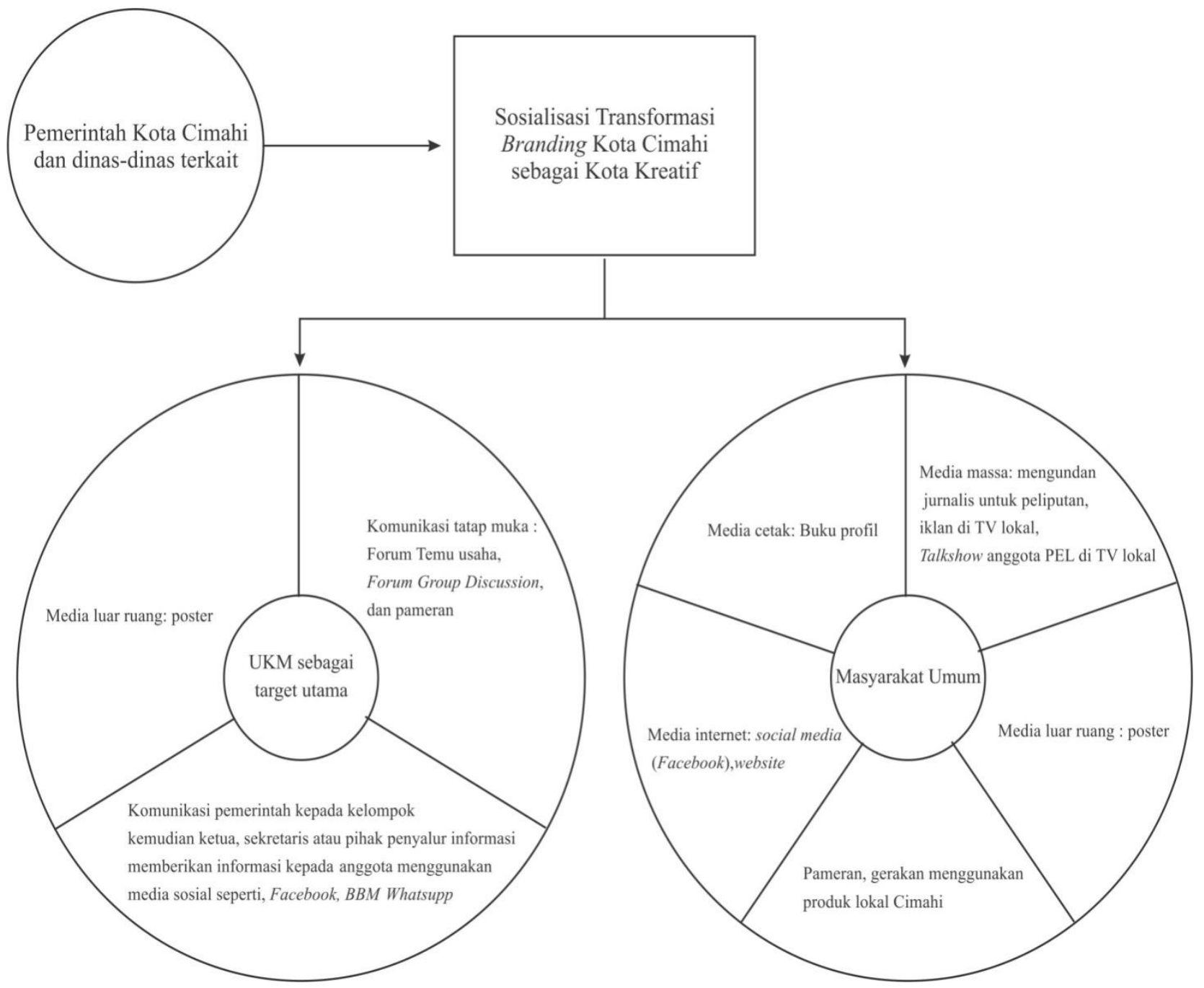


Gambar 1. model pola komunikasi kampanye perubahan merek kota Cimahi sebagai Creative City yang dilakukan Pemkot Cimahi kepada pelaku usaha UMKM dan masyarakat di Cimahi.

\section{PEMBAHASAN}

Sosialisasi perubahan merek Kota Cimahi sebagai Creative City termasuk dalam tahap mengkomunikasikan (communication). Dalam tahap ini informasi mengenai langkah-langkah yang harus dilakukan untuk menimbulkan kesan-kesan positif yang mempengaruhi stakeholder untuk memberikan dukungan terhadap program. Pemkot Cimahi menginformasikan apa saja yang telah dilakukan dan apa yang akan dilakukan kepada target audiens kampanye ini.

Perumusan komunikasi image kota sebagai salah satu cara untuk membentuk brand. Hal yang penting untuk manajemen dan pemasaran kota adalah poin interaksi. Poin ini berarti persepsi terhadap kota, yang dibentuk oleh setiap individu yang tinggal di sebuah kota. Hal itulah yang disebut dengan image kota. Segala sesuatu berasa di kota tersebut atau identik di kota tersebut maka itulah pesan mengenai image kota tersebut.. Hal inilah yang membentuk brand.

Pembentukan brand adalah dengan perumuskan komunikasi image kota melalui sosialisasi dengan pola-pola komunikasi tertentu sesuai dengan target audiens yang ingin dicapai.

Secara konsep proses pembentukan brand kota dapat dijelaskan melalui place branding model berikut: 


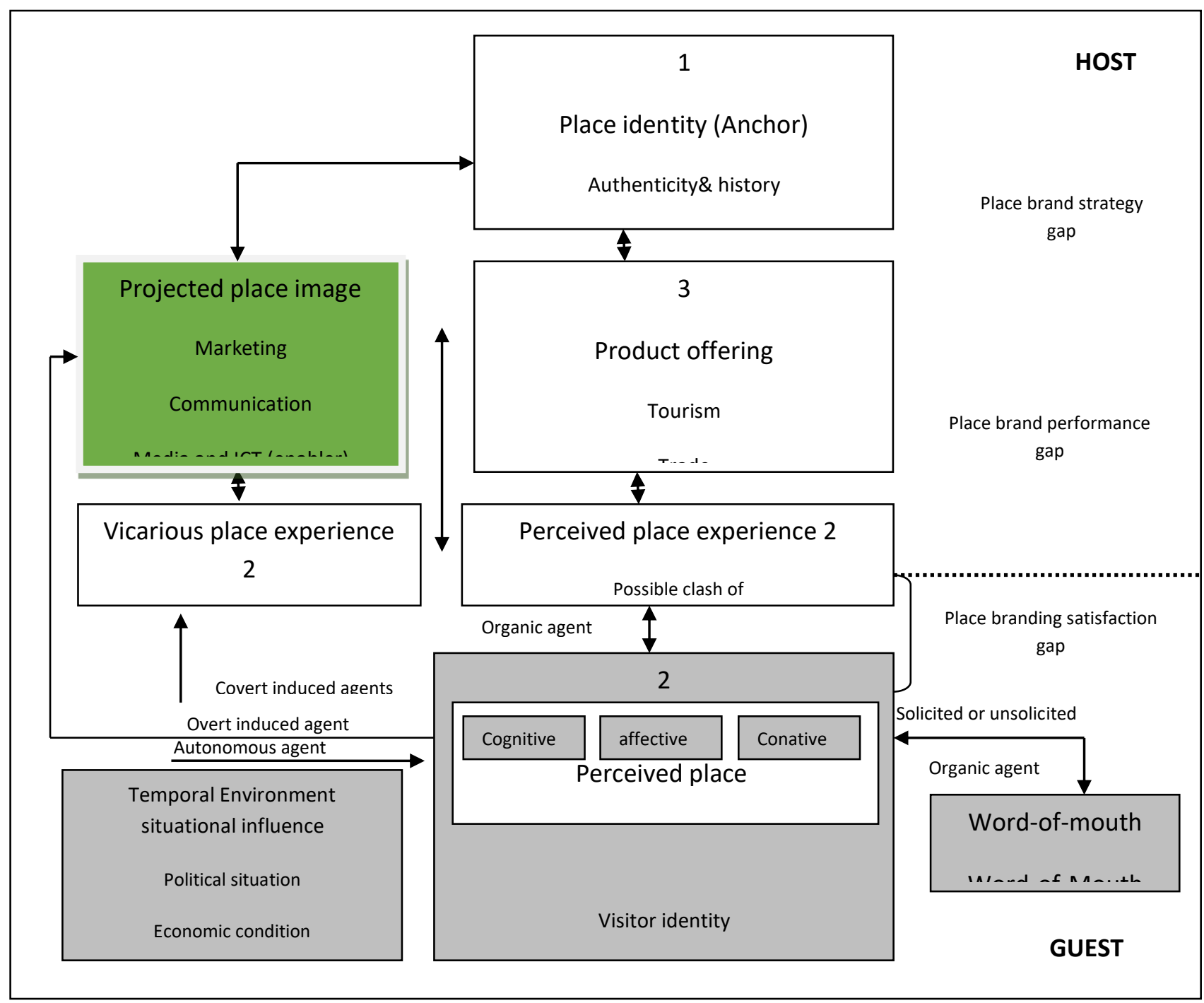

Gambar 2. The 3-Gap Place Branding Model. -gap service quality analysis model dari Parasuraman et al (1985, p.44) dan kontribusi mayor dari Baloglu dan Mcleary (1999), Fesenmaier dan Mckay (1996) dan Gartner (1993). (Govers dan Go, 2009: 41)

Dalam model berikut dijelaskan pembentukan brand ini mencoba untuk mendekonstruksi branding untuk tempat dan pembentukan citra untuk mengidentifikasi elemen-elemen yang memiliki pengaruh dinamis bagaimana brand tempat dirumuskan dalam benak konsumen. Dapat dijelaskan berdasarkan nomor, pada nomor 1 merupakan penjabaran identitas tempat yang telah dijelaskan pada pembahasan latar belakang perubahan merek Kota Cimahi sebagai Creative City, yaitu identitas tempat apa yang akan ditonjolkan adalah potensi ekonomi lokal Kota Cimahi yang dilihat dari UMKM yang memiliki produk kreatif. Pada nomor dua, dijelaskan mengenai pengetahuan atau pengalaman apa yang akan dibagikan kepada visitor mengenai Kota Cimahi. pada nomor tiga, 
dijelaskan mengenai produk kota apa yang akan ditawarkan berdasar pada kegiatan atau program kerja yang dilaksanakan oleh penyelenggara yang tentu saja trade (perdagangan) dan talent (pelaku usaha) dan yang terakhir yang akan ditelaah dalam pembahasan kali ini adalah nomor 4, dijelaskan pola komunikasi untuk mensosialisasikan perubahan merek Kota Cimahi sebagai Creative City pendekatan integrated marketing communication dengan menggunakan berbagai media dan bentuk-bentuk komunikasi.

Pola komunikasi adalah suatu tindakan sistematis yang oleh satu orang atau lebih, yang mengirim dan menerima pesan yang terdistorsi oleh gangguan (noise), terjadi dalam suatu konteks tertentu, mempunyai efek tertentu, dan ada kesempatan untuk melakukan feedback". (Joseph A. Devito, 1997 :23)

Pola komunikasi yang diterapkan oleh Pemkot Cimahi untuk mensosialisasikan perubahan merek Kota Cimahi sebagai Creative City terbagi atas dua kategori, yaitu kepada UKM sebagai target utama dan masyarakat umum melalui pendekatan integrated marketing communication yaitu memasarkan benda atau jasa dengan menggunakan berbagai channel media, yaitu advertising, saluran televisi, business show, promotion, publication, event, Public relations. (Harris, 1991: 35-36). Andrea Insch mengungkapkan :

"Komunikasi merek tidak lagi mengirimkan pesan ke khalayak pasif. pesan tidak dapat dikontrol. Pertimbangan harus diberikan untuk bagaimana penonton yang dipilih dapat dicapai dan diundang untuk berpartisipasi dalam dialog tentang kota dan penawaran. selain produk saluran media tradisional, ada peningkatan penggunaan media sosial interaktif untuk membangun merek" (Dinnie, Keith, 2011: 13)

Target audiens sekarang lebih beragam dalam menggunakan media sehingga selain menggunakan media tradisional dalam sosialisasi ini digunakan pula media sosial seperti Facebook, BBM, Whatsupp. Serta media berbasis internet seperti website resmi pemerintah Cimahi. Hal ini dilakukan seperti yang dikatakan oleh Andrea agar target audiens dapat dicapai dan bisa turut berpartisipasi tentang pembangunan kota.

Pola komunikasi ini pun menerapkan berbagai bentuk komunikasi yaitu, komunikasi interpersonal, komunikasi massa, komunikasi organisasi. Berikut merupakan pembahasan pola komunikasi Pemkot Cimahi untuk mensosialisasikan perubahan merek Kota Cimahi sebagai Creative City:

1. Pola sosialisasi menggunakan komunikasi massa

Komunikasi massa adalah komunikasi yang dilakukan oleh lembaga kepada khalayak yang sangat luas, disalurkan melalui media audio visual, audio atau visual. Tujuannya adalah menghibur, meyakinkan (mengukuhkan, mengubah, mengaktifkan), menginformasikan, mengukuhkan status, membius, menciptakan rasa persatuan. (De Vito, 1997: 24) Komunikasi massa yang kepada UKM dilakukan dengan belowthe line advertising yaitu jenis iklan yang tidak dikenakan komisi dan 
biasanya dikenakan biaya untuk membuat material iklannya. Biasanya yang digunakan adalah media luar ruang seperti poster. Namun untuk target masyarakat luas selain below-the line, digunakan pula above-the line advertising yaitu iklan yang dikenakan komisi dalam pemasangannya seperti iklan di televisi (Wilmhurst dan Mackay, 1999:129) ,media relations yaitu dengan mengundang jurnalis untuk peliputan acara. Public relations, yaitu dengan membuat talkshow anggota FK-PEL atau dengan print media seperti company profile. Company profile adalah kumpulan gambar tertulis tentang sebagian fakta perusahaan yang disajikan secara resmi. Tidak semua fakta ditampilkan karena perusahaan dapat memilih dan membatasi pada hal-hal yang ingin diberikan kepada target audiens (Ardianto, 2011: 157). Company profile digunakan untuk membentuk citra dan reputasi lewat tulisan dan gambar. Filosofi, moto atau sistem nilai Kota Cimahi disampaikan secara tertulis karena memerlukan perenungan untuk menafsirkannya. Company profile mempunyai keunggulan dibanding media lain dalam menunjukkan karakter atau pribadi Kota Cimahi dan memberikan pengertian yang benar bagi stakeholder mengenai apa pun yang terkait Kota Cimahi kepada khalayak, termasuk kebijakan, strategi, program dan kegiatan perubahan merek Kota Cimahi sebagai Creative City.

2. Pola Komunikasi menggunakan komunikasi interpersonal

Komunikasi interpersonal adalah penyampaian pesan oleh satu orang kepada satu orang lainnya atau sekelompok kecil, dengan berbagai efek dan dengan peluang untuk memberikan feedback segera. Komunikasi interpersonal yang dibangun untuk mensosialisasikan perubahan merek Kota Cimahi sebagai Creative City kepada UKM dengan menggelar Forum Temu Usaha yang mempertemukan para pelaku usaha di Cimahi untuk membicarakan berbagai hal mengenai kewirausahaan yang berkenaan dengan perubahan merek Kota Cimahi sebagai Creative City. Sementara kepada masyarakat luas digelar berbagai pameran agar terjalin komunikasi antar pelaku dan masyarakat luas. Selain itu

3. Pola komunikasi dengan komunikasi organisasi

Komunikasi organisasi merupakan pengiriman dan penerimaan pesan didalam organisasi didalam oleh kelompok formal maupun informal organisasi. Komunikasi formal adalah komunikasi yang disetujui oleh organisasi itu sendiri dan sifatnya berorientasi pada organisasi. Isinya berbagai pekerjaan yang harus dilakukan dalam organisasi: memo, kebijakan, pernyataan, jumpa pers, dan surat-surat resmi. Organisasi informal adalah komunikasi yang disetujui secara tidak atas nama lembaga. Orientasinya tidak pada organisasinya sendiri, tetapi lebih pada para anggotanya secara individual. (De Vito, 1997: 340)

Komunikasi organisasi yang dilakukan pemerintah kepada pelaku usaha tergolong komunikasi lateral, karena pemerintah disini bukan atasan namun mitra dari organisasi UKM di Cimahi dalam mengembangkan ekonomi lokal. Yang dilakukan komunikasi informal berupa pertemuan-pertemuan untuk mengakrabkan pemerintah dan 
pelaku usaha, serta komunikasi formal berupa FGD atau kumpul resmi atas undangan dari pemerintah kepada kelompok pelaku usaha yang diwakilkan kepada ketua atau sekretaris mengenai kebijakan, program kerja atau kegiatan yang akan dilakukan untuk pengembangan ekonomi lokal. Dalam komunikasi organisasi pun jelas terdapat proses komunikasi interpersonal, jika wakil dari kelompok usaha yang diajak untuk diskusi menyampaikan kepada anggotanya menggunakan media sosial seperti Facebook, BBM, dan Whatsaupp dan anggota menyampaikannya kepada anggota lainnya. Anggota organisasi menyampaikan kepada masyarakat menggunakan media sosial Facebook. Tak hanya anggota komunitas UKM yang mensosialisasikan perubahan merek Kota Cimahi sebagai Creative City. Pemerintah pun melakukan komunikasi organisasi lateral kepada masyarakat dengan menggunakan website dan gerakan cinta produk lokal. Pemerintah, pelaku usaha, komunitas dan masyarakat merupakan organisasi yang lateral, tidak ada atasan dan bawahan karena semuanya merupakan mitra dalam pengembangan kota melalui perubahan merek Kota Cimahi sebagai Creative City.

\section{KESIMPULAN}

Pola komunikasi yang dibangun Pemkot Cimahi kepada dua target audiens yaitu pelaku UMKM dan masyarakat dalam kampanye perubahan merek Kota Cimahi sebagai Creative City terbagi atas beberapa pola komunikasi diantaranya pola komunikasi interpersonal dengan melaksanakan Forum Temu Usaha yaitu sebuah seminar dan workshop yang menghadirkan berbagai pakar wirausaha yang diundang oleh Pemkot Cimahi serta komunitas wirausaha Cimahi diantaranya Cimahi Creative Association (CCA) yang bergerak di bidang teknologi animasi, Ikatan Wanita Pengusaha Indonesia (IWAPI) regional kota Cimahi, Komunitas Kewirausahawan Muda Cimahi (KWACI). Sementara pola komunikasi organisasi yang dilakukan pemerintah kepada komunitas wirausaha dengan menggunakan media sosial seperti, Facebook, BBM dan Whatsapp, selain itu pola komunikasi organisasi pun dilakukan dengan menggunakan media luar ruang seperti poster yang ditempel di tempat-tempat pertemuan komunitas wirausaha dan mading Pemkot Cimahi, menyelenggarakan pameran kewirausahaan, membuat gerakan "Cinta Produk Lokal Cimahi", membuat website PEL, promosi menggunakan media sosial seperti Facebook serta, melaksanakan Forum Group Discussion.

Sosialisasi pun dilakukan dengan pola komunikasi massa yang dilakukan oleh Pemkot Cimahi kepada masyarakat umum untuk mensosialisasikan perubahan merek Kota Cimahi yaitu dengan mengundang jurnalis untuk peliputan dan penayangan di TV nasional maupun lokal, memasang iklan di TVRI, dan menyelenggarakan Talkshow anggota PEL menayangkan TVRI, dan membuat buku profil komunitas wirausaha Cimahi. 
Untuk penelitian lebih lanjut, maka akan dilakukan studi penelitian perbandingan branding Creative City, hal ini akan memberikan warna baru bagi studi komunikasi pembangunan serta memberikan masukan kepada pemerintah mengenai bagaimana membangun suatu image branding Creative City yang sesuai dan baik.

\section{DAFTAR PUSTAKA}

Ardianto, Elvinaro.(2007). Filsafat Ilmu Komuikasi. Bandung: Remaja Rosdakarya

Creswel, John.W. (2012). Research Design: Pendekatan Kualitatif, Kuantitatif dan Mixed. Yogyakarta: Pustaka Pelajar

Dinnie, Keith. (2011). City Branding: Theory and Cases. New York: PALGRAVE MACMILLAN DeVito, Joseph A. (1997). Komunikasi antar manusia, edisi 5. Jakarta : Profesionial Book

Govers, Robert dan Frank Go.(2009). Place Branding: Glocal, Virtual and Physical Identities, Constructed, Imagined, Experienced. New York: PALGRAVE MACMILLAN

Harris L, Thomas. (1991). The Marketers Guide To Public Relations. Canada: John Willey \& Sons, inc

Suparno, P. (1997). Filsafat Konstruktivisme dalam Pendidikan. Cet. Ke-7. Yogyakarta: Kanisius

Wilmhurst, John dan Adrian Mackay. (1999). The Fundamentals of Advertising: Second Edition. Oxford: Biddles Ltd

Yin, K. Robert. (2006). Studi Kasus, Desain dan Metode. Jakarta: Raja Grafindo Persada

Jurnal cetak Pemkot Cimahi. (2013). Dokumen Rencana Strategis Pengembangan Ekonomi Lokal (PEL) Kota Cimahi tahun 20132018 